\title{
MORAL HAZARD IN DEPOSIT INSURANCE: THE CASE OF FOBAPROA
}

\author{
Clemente Hernández Rodríguez* \\ Escuela de Graduados en Administración y Dirección de Empresas \\ Tecnológico de Monterrey, Campus Guadalajara
}

(Received 10 February 2005, accepted 27 May 2005)

\begin{abstract}
This paper is two-fold. First, it presents the institutional setting (deposit insurance schemes) of the Mexican commercial Banking system. Second, It shows, using a probit model, that there was a moral hazard problem under FOBAPROA. One of the findings is that FOBAPROA encourages banks to hold less capital relative to assets under a private regime than under government control. I also find that FOBAPROA influences the loan-to-assets ratio. I do not find evidence, however, that FOBAPROA encourage banks to hold lower surplus-to-loans or reserve-to-deposits. Because of moral hazard associated with deposit insurance, troubled banks that had a small surplus-to-loans ratio have an incentive to take speculative positions.

\section{Resumen}

Este artículo se divide en dos partes. Primero, presenta el escenario institucional (los esquemas de seguros de depósitos) del sistema de la banca comercial en México. Segundo, muestra, usando un modelo probit que bajo FOBAPROA había un problema de riesgo moral. Uno de los hallazgos es que en un régimen privado FOBAPROA impulsa a los bancos a tener menos capital relativo a activos que cuando estaban bajo control gubernamental. También encuentro que FOBAPROA influye en la razón préstamos a activos. Sin embargo, no encuentro evidencia, de que FOBAPROA anime a los bancos a tener una razón baja en excedentes a préstamos o en reservas a depósitos. Debido al riesgo moral asociado con el seguro de depósitos, los bancos en problemas, que tienen una razón pequeña de excedentes a préstamos, tienen un incentivo a tomar posiciones especulativas.
\end{abstract}

JEL classification: C35, D82, G21, N26

Keywords: FOBAPROA, Moral Hazard, Government Deposit Insurance, Probit Model

* E-mail: clemente.hernandez@itesm.mx 


\section{Introduction}

Most countries have adopted a deposit insurance system in order to protect the financial system stability. The creation of the FOBAPROA ${ }^{1}$ is part of the background of the Mexican federal government's concern to protect the banking depositors, specifically the savers. Deposit insurance is only a part of several arrangements for the protection of the financial agents and, therefore, not all the countries operate formal deposit insurance schemes. ${ }^{2}$ A major characteristic of government deposit insurance is information asymmetry that may lead to phenomena such as adverse selection and moral hazard.

There are diverse studies about the problems of asymmetric information generated in the financial world. In these models, once the money is deposited, the moneylender is exposed to a problem of moral hazard when there is the possibility that the bank undertakes riskier behavior. Consequently, the possibilities of the deposit recoverability, in case of a bank run, decrease. The banks are forced to participate in riskier projects, hoping that these projects will yield enough to cover the debt. So the bank will no longer be willing to be part of low-risk projects, since the probability that the yields are enough to cover the debt is low. The problem of moral hazard is not given by a change in the composition of the banks, but because the banks changed their attitude toward the risk. The depositors have information with regard to the absolute and relative quality of the banks, but they do not know how responsibly they are administered; neither do they know if their loan policies are risky or conservative. This might lead to a bank run; that is, the depositors arrive in mass in order to withdraw their savings Stiglitz and Weiss (1981).

Diamond and Dybvig (1983), Kane (1985, 1989), O'Driscoll (1988), and Wheelock and Kumbhakar (1995), among many economist have identified government deposit insurance as an important contributor to the large number of bank and saving and loan failures in the past years in the U.S. For instance, Alston, Grove, and Wheelock (1994) and Wheelock and Wilson (1995) show that bank failures rates were greater in states with deposit insurance systems, after controlling for branch banking, other government policies and differences in economic activity across states.

It has been argued that FOBAPROA, the Mexican government deposit insurance, led to moral hazard problems in the Mexican banking sector (See González-Anaya (2002), Hernández and López (2001), among others). However, it has not been tested. The main goal of this paper is to show that moral hazard problem was present in the Mexican banking system when FOBAPROA was adopted. The way I proceed is by running probit models. The relevant hypothesis tested is the following: the adoption of FOBAPROA increased the incidence of individual bank disappearance. To test moral hazard the dependent variable is participation in FOBAPROA or FONAPRE regime.

The first finding is that FOBAPROA encourages banks to hold less capital relative to assets under a private regime than under government control.

1 FOBAPROA means Bank Fund for the Protection of Savings.

2 In fact, two types of deposit insurance coverage can be identified: (1) explicit insurance coverage, where there are formal deposit insurance, and (2) implicit insurance coverage, where prior experience implies that the government will take steps to protect the banking system. 
Apparently the incentive to hold reserves provided by the insurance premium structure was too small to prevent insured banks from choosing greater leverage. A second finding is that FOBAPROA influences the loan-to-assets ratio. I do not find evidence, however, that FOBAPROA encourage banks to hold lower surplus-to-loans or reserve-to-deposits. Deposit insurance removes the incentive for depositors to monitor bank risk, and thereby encourages banks to substitute deposits for equity and to maintain greater portfolio risk than they otherwise would. Because of moral hazard associated with deposit insurance, troubled banks that had a small surplus-to-loans ratio have an incentive to take speculative positions.

The remainder of this paper is divided as follows. The next section sketches the institutional setting in the Mexican Banking System. Section 3 describes the banking bailout package after the Peso Crisis. The fourth section describes the data used. Section 5 proposes a probit regression and presents results. The last section presents the conclusions.

\section{The Institutional Setting}

In the early $1980 \mathrm{~s}$, there was no explicit deposit insurance system in Mexico. At that time, the close relationship between the commercial bank and the federal government was an implicit guarantee over deposits, where the central bank, Banco de México, was the lender of last resort. When banks were under governmental control, the Ley de Instituciones y Organizaciones A uxiliares de Crédito (Law of Credit Institutions and Credit Auxiliary Organizations) mentioned the Fund for the Protection of Credits of Banking Institutions, FOPROCRE, but it was never established.

The Preventive Support Fund, FONAPRE, was established in 1986 by the Ley Reglamentaria al Servicio Público de Banca y Crédito (Prescribed Law for the Public Service of Banking and Credit). FONAPRE replaced the never set up FOPROCRE. The goal of FONAPRE was to avoid insolvency in the credit entities. FONAPRE was no part of the federal public administration. In 1987, FONAPRE solved some problems in the banking entities, evaluating and giving attention to problems of endorsed institutions. In 1988, six national credit societies were specially supervised because they were subject to correctives (or other specific actions). Thus, since its foundation and up to 1990, FONAPRE helped to eight banks. Seven were rehabilitated and one was merged by suggestion of FONAPRE.

The privatization process ${ }^{3}$ of the commercial banking system in Mexico started in 1989 and finished in 1992 (Privatization was headed by the SHCP's bank privatization committee). In the meantime, banks contributed monthly to

3 In the banking privatization process, the government put heavy emphasis on selling to the highest bidder and paid scant attention to the quality and experience of the buyers. At the same time, the Government opened up the financial sector to a new concept the universal-banking framework, which permitted commercial and investment banking to mix with brokerage and all the other financial activities under the same banking firm. In contrast, most countries in the world maintained strict regulations forbidding this type of behavior, given the different inherent nature of each activity. Heath (1999). 
FONAPRE. Those contributions were $\$(1 / 12)$ to $\$ 1,000$ the daily average balance by month of the liabilities in local currency considered as reception for the Multiple Bank investment regime. On January 1990, such contributions became $\$ 3$ to $\$ 1,000$. Furthermore, added to changes in laws and regulatory changes, the FOBAPROA was created. Banks were under obligation to contribute to FOBAPROA.

On July 1, 1990 the Ley de Instituciones de Crédito (Financial Groups Law) was issued. This law regulates the operation of the privatized commercial Mexican banking sector. Article 122 of this Law replaced FONAPRE, the insurance system for the Mexican Commercial Banking Institutions in the late 1980s, by FOBAPROA. ${ }^{4}$ FOBAPROA was a trust administered by the central bank (Banco de México), created for preventive support to commercial banks and to protect savings. FOBAPROA's Technical Committee was formed by representatives of the treasury ministry (SHCP), the central bank and the Banking National Commission (CNB). The aim of FOBAPROA was to avoid financial problems in the multiple bank institutions, and consequently, avoid lack of liquidity and capacity constraints to accomplish the commitment with depositors. Then, when the crisis happened in 1995, the banking bailout was implemented by FOBAPROA.

The law did not obligate FOBAPROA to explicitly guarantee or insure any obligations of commercial banks. Nevertheless, each December, FOBAPROA used to announce the maximum amount of the obligations it intended to protect. In general, FOBAPROA expressed an intention to protect all deposits, even though FOBAPROA was not a explicit deposit insurance scheme and was not liable in the event of an uncovered default. For the period analyzed, FOBAPROA implicitly protected 100 percent of deposits. The legislation on deposit insurance does not distinguish between small and large deposits. Due to legal restrictions, almost 100 percent of deposits are held in local currency.

On December, 1998, the Ley de Protección al Ahorro Bancario (Law for Protection of Bank Savings), created the Institute for the Protection of Bank Savings, IPAB. FOBAPROA was replaced in May 1999 by IPAB. Before IPAB, Mexico had no formal system of deposit insurance. Both deposit insurance systems, FONAPRE and FOBAPROA, were implicit deposit insurance NaranjoGonzález (2002).

\section{The Banking Bailout Package after the Peso Crisis}

The Peso crash in 1995 was severe but short lived. The crisis struck a large shock to the banking system Kaminsky and Reinhart (1999). The devaluation hurt bank's balance sheet directly through their foreign exchange exposure, and indirectly because firms who borrowed in dollars but sold their goods in pesos were not able to pay. In addition the combination of the fall in economic activity and the rise in real interest rates above $17 \%$ left many firms unable to meet their obligations. As a result Mexican banks were left undercapitalized. ${ }^{5}$

4 This deposit insurance scheme is very similar to the current schemes in developed countries. It is very efficient to face isolated problems. but is very limited to face a generalized crisis as the one in 1995 in Mexico.

5 There are many papers that analyze the Peso Crisis and its effects on the banking 
The government took several measures to reduce the current account deficit, prevent inflation from rising, and avoiding a meltdown of the banking system. The measures included fiscal and monetary tightening as well as a support package from the U.S. treasury, the IMF and the World Bank amounting to US $\$ 52$ billion. The measures to resolve the banking crisis can be grouped into three categories. First, a liquidity assistance program that provided short-term foreign currency loans at penalty rates so that banks could honor their external lines of credit and their foreign exchange exposure. Second, debtor support programs of various sorts. Some reduced interest payments to debtors able and willing to repay their debts in their original conditions while the government paid the costs of interest reductions. Others included a loan indexation mechanism that allowed loans to be restructured in a constant value unit of account (UDIs) and at a constant real interest rate based of forward looking inflation expectations. There were also some debtor programs targeted for mortgages, the agricultural sector, and small and medium size business.

The final and costliest measure included two forms of open bank assistance (FOBAPROA (1998), various issues): The first program, called PROCAPTE, subsidiary of FOBAPROA, was designed to increase bank assets to face rising past due loans in order to aid banks in reaching a capital asset ratio higher than $8 \%$. Banks who agreed to participated in this program were allowed to issue five year convertible bonds which would be purchased by the government and the proceeds would the have to be converted to equity capital. There was a strong incentive to raise the capital quickly because the bonds were charged a premium over the interbank rate. If the bank failed to meet the $8 \%$ capital-asset ratio by a pre-established date, the bank would be taken over by the authorities. Unfortunately, the program did not work because the market considered participation as a sign of weakness or as a prelude to (government) intervention Mackey (1999).

The second open bank assistance program and the one that actually was implemented fully was a loan purchase where banks swapped non-performing loans in exchange for non-tradable, 10 year bonds with interest rates linked to Mexican Treasuries (CETES). The program was implemented by FOBAPROA (IPAB since May 1999). The purpose of the program was to give banks a "clean slate" so they could return to profitability and lending. One condition to enter this program was the following: for every two pesos of non-performing loans that the government acquired, the shareholders should invest one peso of fresh capital in the bank. The idea was that this program would increase bank capitalization at the same time and as the economy recovered banks would get rid of non-performing loans, and return to profitability and lending.

The terms of the bonds were negotiated individually with each bank that participated in the program. The idea was to tailor make the bailout package for each bank in order to lower the cost. Ex post the distribution assumptions of bad loans is hard to explain. ${ }^{6}$ In general, the interest rates of the bonds are fixed to a specific market interest rate: CETES, Mexican Treasuries, or the

financial system. Krueger and Tornell (1999) provide a good compilation of papers.

6 For instance, Bancrecer, a small bank, swapped bad loans for bonds worth 10 billion dollars. 
TIIE, the inter-bank interest rate (the equivalent of the Federal Funds rate). In retrospect, it appears the returns are high with a few points above or below the reference rate indicating the authorities were not able to reduce the cost much.

The loan purchase program was not done once and for all because the share of non-performing loans kept increasing and banks failed to recapitalize. ${ }^{7}$ The temporary bailout program became an open-ended bailout mechanism. Not surprisingly, past due loans continued to increase even as bad loans were taken of the balance sheets Desmet K. (2000). The ratio of past due loans to total loans increased from $8.7 \%$ in 1994 , to $16.4 \%$ in $1995,21.4 \%$ in 1996 , and $29.8 \%$ in $1997 .^{8}$ All of this despite the fact the economy recovered at a fast pace -it grew at $5.4 \%$ during the 1996-2000 period while inflation fell from above 50 percent in 1995 to single-digit levels in 2000. La Porta Lopez-de-Silanes, and Zamarripa (2003) present a convincing case that the main reason nonperforming loans continued to increase was that related lending increased once it became obvious that there was going to be a bailout.

The crucial result from the banking bailout is that, the bank's asset portfolio shifted substantially into IPAB bonds (also called pagarés-IPAB, FOBAPROA bonds or pagarés-FOBAPROA). During a takeover, the acquiring bank would also acquire the bailout bonds that the target bank had in its portfolio leading to an important concentration of bailout bonds. The remarkable fact is that after the mergers there are only six banks that hold IPAB bonds: BBVABancomer, Banamex-Citibank, Santander-Serfin, Bital, Banorte, ScotiabankInverlat. ${ }^{9}$

There were no bank liquidations or closed bank resolutions at all during the crisis. The attitude was that "authorities had to act promptly to provide liquidity and maintain the integrity of the banking system: otherwise, deterioration of the system's financial situation (or some of its segments) could have spread quickly to the business sector." (Gavito, Silva, and Zamarripa (1998)). The Mackey Report (Mackey (1999)) noted that the Mexico followed a policy "that no banks would fail and that bank operations would "regularized" rather than liquidated." Mexican authorities wanted to avoid a systemic bank problem at all costs. They succeeded in avoiding a systemic crisis but the costs were

7 It is not clear if this implies a strict renegotiation of maturities and rates or if these transactions included reductions or increases in the loan. Moreover, it is not clear why there is such a high concentration of renewals at the end of the Zedillo administration.

8 The increase between 1996 and 1997 is mostly because the Banking Supervision agency (CNBV) changed its methodology. Under the new standards, which follow the Basil guidelines more closely, the value of a past due loan is reported as the total unpaid balance, capital and interest, rather than only the amount that was delinquent.

9 At the same time these are the biggest banks accounting for $93 \%$ of the total assets of the banking system. Since IPAB bonds were swapped for loans, for accounting purposes keep them as part of their good standing loans. In the case of Banorte it almost doubles the amount of loans in good standing. The three largest banks, Banamex, Bancomer and Serfin which control about $60 \%$ of assets in the banking system also held $48 \%$ (CNBV (2003)) indicating that the fact they were larger banks did not make them inore immune to crisis. 
enormous, ${ }^{10}$ the bailout has perverse incentives which prevent banks from returning to lending González-Anaya (2002). Moreover, the approach encouraged outright illegal behavior from bank owners, ${ }^{11}$ and more importantly, the fifth section will argue that FOBAPROA generates incentives for moral hazard in the Mexican commercial banking system.

\section{Data}

I have collected data for a panel of banks covering the period 1982 though 1998 . The data consist of a panel of Mexican banks for which I collected balance sheet and other information covering this period. The sample includes the Mexican banks that existed in the period above mentioned. All data for individual banks are from the quarterly report of the Bank and Securities National Commission, CNBV (2003) (former CNB) various years.

Bank disappearance means that the bank is out of business because it merges another bank or is intervened by the government. The variable assets, to control for size, includes total bank assets. Age is the number of years between a bank's charter and balance-sheet date.

Various financial ratios that are plausibly related to the probability of bank disappearance are included: the ratio of the book value of bank equity to total assets (CAP_TA); the surplus and undivided profits to loans ratio (SUR_LOANS); the ratio of total loans to total assets ( $\left.L O A N \_T A\right)$; The ratio of cash items, currency and coin to total deposits (RES_TD); and the ratio of borrowed funds (bills payable or rediscounted) and miscellaneous liabilities to total assets ( $\left.L I A B \_T A\right)$.

I look at the impact of the FOBAPROA (and of the FONAPRE) measured with a dummy variable, FBP, equal to 1 for the period under FOBAPROA and 0 for the period under FONAPRE. If the FOBAPROA thereby increased the individual bank probability to need bailout, the coefficient on the FBP dummy variable should be positive.

The following macroeconomic variables ${ }^{12}$ are included: the balance of payments $(B P A Y)$, reported quarterly by Banco de Comercio Exterior; the exchange rate peso per dollar $(E X C H)$, reporter quarterly by Banco de México; the inflation rate $(I N F)$ quarterly reported by Banco de México, and INEGI; and the growth rate of the Mexican GDP $(\triangle G D P)$, reported quarterly by Banco de México, and INEGI.

10 The government banking bailout prevented a systemic collapse of the banking sector that cost more than US\$55 billion. Estimating the cost of resolving the Mexican banking crisis is time dependent and non trivial. Krueger and Tornell (1999) show the present value of the costs at the end of a given year divided by the GDP of that year from Banco de México. The costs are $5.5 \%$ in $1995,8.4 \%$ in 1996 , and $16.2 \%$ in 1998 . Caprio and Klingebiel (1999) estimate the costs at around $21 \%$ of GDP. Today the FOBAPROA's bond liabilities reach close to US\$55 billion and the value of the assets is uncertain. Thus, as long as authorities resist the temptation to continue to carry out loan purchases, this will be the upper bound.

11 See La Porta et al. (2003) for convincing documentation of increased related lending once it became obvious that there was going to be bailout.

12 Source Banco de México (2003), Banco de Comercio Exterior (2003), and INEGI (2003). 


\section{Empirical Evidence of Moral Hazard}

The purpose of this section is to develop a model in order to evaluate moral hazard. By using panel data, I will develop a probit model for the analysis. I expect that FOBAPROA may have created moral hazard, encouraging banks to hold less capital and more risky portfolios than banks when FOBAPROA was not present. In turn, this could provoke bank disappearance, $i$. e. moral hazard. Balance-sheet comparisons indicate that banks disappear were less capitalized than banks that did not need it. The capital-to-asset ratio is not the only possible risk measure available, and I also test whether deposit insurance caused differences across banks financial ratios. If moral hazard characterized the Mexican deposit insurance system, I expect to find that the FOBAPROA presence had a negative impact on the surplus-to-loans and reserve-to-deposit ratios of the Mexican commercial banks, and a positive impact on their loansto-assets ratio.

Although financial ratios reflect a bank's condition, they are ex-post measures of risk-taking, and thus could reflect circumstances beyond a bank's control. To explain a bank's risk-taking, I include bank age. I also include macroeconomic variables to capture the local circumstances that might have caused financial condition of banks to vary systematically in Mexico. Aside from competitive changes induced by the increase of number of banks, capture in age, I included the balance of payments $(B P A Y)$. Similarly, the financial ratios were influenced by the exchange rate $(E X C H)$ and the inflation rate $(I N F)$, and the growth rate of Mexican $G D P(\triangle G D P)$.

One issue that $I$ worry about in the earlier regressions is endogeneity. In order to cope with this problem I employ a two-stage procedure Greene (2000), where the insurance variable is instrumented out of the model (FBP_EST). The estimated equations for the second stage are:

$$
\begin{aligned}
S U R \_L O A N & =C O N S T_{I}+\gamma_{I 1} F B P \_E S T+\gamma_{I 2} A G E+\gamma_{I 3} B P A Y \\
& +\gamma_{I 4} E X C H+\gamma_{I 5} I N F+\gamma_{I 6} \Delta G D P+U_{I},
\end{aligned}
$$

$$
\begin{aligned}
C A P \_T A & =C O N S T_{I I}+\gamma_{I I 1} F B P \_E S T+\gamma_{I I 2} A G E+\gamma_{I I 3} B P A Y \\
& +\gamma_{I I 4} E X C H+\gamma_{I I 5} I N F+\gamma_{I I 6} \Delta G D P+U_{I I},
\end{aligned}
$$

$$
\begin{aligned}
R E S \_T D & =C O N S T_{I I I}+\gamma_{I I I 1} F B P \_E S T+\gamma_{I I I 2} A G E+\gamma_{I I I 3} B P A Y \\
& +\gamma_{I I I 4} E X C H+\gamma_{I I I 5} I N F+\gamma_{I I I 6} \Delta G D P+U_{I I I},
\end{aligned}
$$

$$
\begin{aligned}
L O A N \_T A & =C O N S T_{I V}+\gamma_{I V 1} F B P \_E S T+\gamma_{I V 2} A G E+\gamma_{I V 3} B P A Y \\
& +\gamma_{I V 4} E X C H+\gamma_{I V 5} I N F+\gamma_{I V 6} \Delta G D P+U_{I V} .
\end{aligned}
$$

The second-stage estimates of the effect of FOBAPROA membership on financial ratios are presented in Table 1. 
Table 1. Effects of FOBAPROA on Bank Financial Ratios. Dependent Variable: In Equation I is $S U R \_L O A N$. In equation II is CAP_TA In Equation III is $R E S \_T D$. In equation IV is $L O A N_{-} T A$.

\begin{tabular}{ccccc}
\hline Variable & I & II & III & IV \\
\hline CONST & 10.62 & 4.40 & 26.86 & 66.10 \\
FBP_EST & $(3.33)^{* * *}$ & $(5.16)^{* * *}$ & $(7.52)^{* * *}$ & $(21.03)^{* * *}$ \\
& -3.85 & -19.34 & -3.39 & -11.85 \\
AGE & $(1.16)$ & $(3.26)^{* * *}$ & $(0.32)$ & $(1.68)^{*}$ \\
& 0.16 & -0.03 & 0.04 & -0.08 \\
BPAY & $(5.86)^{* * *}$ & $(0.35)$ & $(0.54)$ & $(1.37)$ \\
& 1.73 & -0.21 & 8.08 & -9.93 \\
EXCH & $(1.70)^{*}$ & $(0.369)$ & $(3.70)^{* * *}$ & $(4.89)^{* * *}$ \\
& -0.01 & 0.04 & -0.01 & 0.02 \\
INF & $(0.40)$ & $(1.91)^{* *}$ & $(1.48)$ & $(0.77)$ \\
& 0.03 & 0.03 & -0.01 & 0.04 \\
$\Delta G D P$ & $(1.26)$ & $(0.89)$ & $(0.45)$ & $(1.39)$ \\
& 0.01 & 0.04 & 0.05 & -0.03 \\
$R^{2}$ & $(2.43)^{* * *}$ & $(0.21)$ & $(0.38)$ & $(0.79)$ \\
\hline
\end{tabular}

*** t-ratios significant at a 0.01 (two-tail test). ** t-ratios significant at a 0.05 (two-tail test). * t-ratios significant at a 0.10 (two-tail test). Standard errors were corrected for heteroscedasticity. Coefficients are multiplied by 100 .

Although FOBAPROA appears to have encouraged banks to hold less capital than it was not present, I do not find systematic impact on surplus-to-loans, or reserve-to-deposits. The FOBAPROA membership influences positively the loan-to-assets ratio (the delinquency index) at a $10 \%$ of significance. After controlling for local conditions, FOBAPROA induced banks to hold significantly less capital than before. The coefficient of -19.34 on FBP_EST provides an estimate of impact of the FOBAPROA: cereteris paribus, a bank maintained a capital-to-assets ratio 19.34 percentage points less than when it was not under FOBAPROA. The negative coefficients signs in the surplus-to-loans and reserveto-deposits regressions are consistent with the hypothesis that FOBAPROA provoked an increase in risk levels, i.e. moral hazard. However, none of the coefficients is statistically significant.

So, although the above analysis shows ex ante moral hazard, it has a shortcoming: its failure to account fully for ex post moral hazard. This two-stage least squares corrects for selection bias. It seems appropriate to capture the relationship between a bank's preference for risk and the FOBAPROA. Thus, I model bank risk and FOBAPROA membership, as a simultaneous system. The estimated equations for the Simultaneous Equation Model are:

$$
\begin{aligned}
\text { Bank Disappearance } & =C O N S T A N T_{I}+\delta_{I 1} S_{-} L_{-} E S T+\delta_{I 2} A G E \\
& +\delta_{I 3} B P A Y+\delta_{I 4} \Delta G D P+e_{I}
\end{aligned}
$$




$$
\begin{aligned}
\text { Bank Disappearance } & =C O N S T A N T_{I I}+\delta_{I I 1} C_{-} A_{-} E S T+\delta_{I I 2} A G E \\
& +\delta_{I I 3} B P A Y+\delta_{I I 4} \Delta G D P+e_{I I},
\end{aligned}
$$

$$
\begin{aligned}
\text { Bank Disappearance } & =C O N S T A N T_{I I I}+\delta_{I I I 1} R_{-}{ }_{-} E S T+\delta_{I I I 2} A G E \\
& +\delta_{I I I 3} B P A Y+\delta_{I I I 4} \Delta G D P+e_{I I I},
\end{aligned}
$$

Bank Disappearance $=$ CONSTANT $T_{I V}+\delta_{I V 1} L_{-} T_{-} E S T+\delta_{I V 2} A G E$

$$
+\delta_{I V 3} B P A Y+\delta_{I V 4} \Delta G D P+e_{I V}
$$

If moral hazard is present, FOBAPROA should increase risk-taking, then higher risk banks will be predominant in the system, increasing the bailout rate and,

\begin{tabular}{|c|c|c|c|c|}
\hline Variable & $\mathrm{I}$ & II & III & IV \\
\hline \multirow[t]{2}{*}{$C O N S T A N T$} & 0.62 & 0.40 & 0.86 & -1.10 \\
\hline & $(2.89)^{* * *}$ & $(2.76)^{* * *}$ & $(2.52)^{* * *}$ & $(1.03)$ \\
\hline \multirow{2}{*}{$S \_L \_E S T$} & -6.85 & & & \\
\hline & $(2.86)^{* *}$ & & & \\
\hline \multirow[t]{2}{*}{$C \_A \_E S T$} & & -4.38 & & \\
\hline & & $(2.85)^{* *}$ & & \\
\hline \multirow[t]{2}{*}{$R \_D \_E S T$} & & & -1.73 & \\
\hline & & & (1.09) & \\
\hline \multirow[t]{2}{*}{$L \_T \_E S T$} & & & & 2.71 \\
\hline & & & & $(2.45)^{* *}$ \\
\hline \multirow[t]{2}{*}{$A G E$} & 0.014 & 0.003 & 0.004 & 0.05 \\
\hline & $(3.39)^{* * *}$ & $(0.93)$ & $(2.23)^{* *}$ & $(2.25)^{* *}$ \\
\hline \multirow[t]{2}{*}{$B P A Y$} & 0.94 & 1.26 & 1.30 & 1.41 \\
\hline & $(12.76)^{* * *}$ & $(16.28)^{* * *}$ & $(17.01)^{* * *}$ & $(16.73)^{* * *}$ \\
\hline \multirow[t]{2}{*}{$\triangle G D P$} & 0.14 & 0.26 & -0.14 & -0.16 \\
\hline & $(1.80)^{*}$ & $(1.46)$ & $(1.88)^{*}$ & $(1.01)$ \\
\hline$R^{2}$ & 0.45 & 0.46 & 0.43 & 0.43 \\
\hline
\end{tabular}
therefore, the bank disappearance probability. These results are presented in Table 2.

Table 2. Results. Simultaneous-Equation Model Estimates. Dependent Variable in every Regression is Bank Disappearance.

*** t-ratios significant at a 0.01 (two-tail test). ** t-ratios significant at a 0.05 (two-tail test). ${ }^{*}$ t-ratios significant at a 0.10 (two-tail test). Standard errors were corrected for heteroscedasticity. Coefficients are multiplied by 100 .

I find that Bank Disappearance was a positive function of bank risk. The coefficient of reserve-to-deposits ratio is also consistent with the presence of moral 
hazard, although it is not statistically significant. FOBAPROA give incentives to the banks to worsen their capital adequacy ratios. FOBAPROA bailed out the banks with low-capital-to-assets ratio. In this manner, the banks in marginally better positions that could benefit from FOBAPROA had incentives to worsen marginally their capital-to-assets ratio in order to benefit themselves from the banking bailout. This was true; whenever the bank estimates that the expected benefit of the support from FOBAPROA was greater than the cost of worsening marginally the capital-to-assets ratio. If support were granted to commercial banks before they faced these incentives, these support programs would have a greater recovering probability than the supports granted to banks closer to disappear. Thus, I do find evidence of moral hazard ${ }^{13}$ from the FOBAPROA regime; $i$. e., once the most risk-prone banks were sure of the banking bailout via FOBAPROA they tended to reduce their capital-to-asset ratios.

\section{Conclusions}

Using balance-sheet information, I estimate a simultaneous-equation model in order to disentangle moral hazard from risk-taking induced by FOBAPROA, and to show that risky banks were benefited the most from this system. The main finding was that FOBAPROA encourages banks to hold less capital relative to assets under a private regime than under government control. Apparently the incentive to hold reserves provided by the insurance premium structure was too small to prevent insured banks from choosing greater leverage. I also find that FOBAPROA influences the loan-to-assets ratio. I do not find evidence, however, that FOBAPROA encourage banks to hold lower surplus-to-loans or reserve-to-deposits. Deposit insurance removes the incentive for depositors to monitor bank risk, and thereby encourages banks to substitute deposits for equity and to maintain greater portfolio risk than they otherwise would.

When a bank gives all its equities in guarantee to FOBAPROA, they will spread their asset to increase the level of the average risk of its credits. It is explained because a bank with a small capital-to-assets ratio has less to lose. If it is able to charge the high risk credits, it will be able to recover the equities from FOBAPROA. If the bank fails, FOBAPROA will incur the losses. The evidence indicates, therefore, that the deposit insurance system, FOBAPROA, suffered from moral hazard problems. Because of moral hazard associated with deposit insurance, troubled banks that had a small surplus-to-loans ratio have an incentive to take speculative positions. The representative agent is risk adverse, hence the system where the investors assume partial responsibility for their deposits, would punish high risk banks, transferring their deposits to low risk banks, phenomena know as market discipline.

13 There is adverse selection in credits. From a theoretical point of view, the existence of a deposit insurance fund that guarantees $100 \%$ of the deposits generates incentives so that the banks with low-capital-to-assets ratio accept to grant high-risk credits. Because of moral hazard associated with deposit insurance, troubled banks that have a relatively thin capital cushion to absorb losses (low-surplus-to-loans ratio) have an incentive to take speculative positions. One can observe that risk-prone banks were benefited of insurance coverage, or bailout, from FOBAPROA. In fact, they were the first to jeint the banking bailout program. 


\section{References}

Alston, L., W. Grove, and D. Wheelock (1994). Why Do Banks Fail? Evidence from the 1920's. Explorations in Economic History, 31, pp. 409-431.

Banco de Comercio Exterior (June, 2003). URL: http://www.bancomext.com

Banco de México. Informe Trimestral sobre el Comportamiento de la Economía Mexicana. México (various issues).

Banco de México (August, 2003). URL: http://www.banxico.org.mx

Caprio, G. and D. Klingebiel (1999). Episodes of Systemic and Borderline Financial Crises. World Bank Working Paper.

CNBV (July, 2003). URL http://www.cnbv.gob.mx

Desmet, K. (2000). Accounting for the Mexican Banking Crisis. Emerging Markets Review, 1 (2000) pp. 165-181.

Diamond, D. and P. Dybvig (1983). Bank Runs, Deposit Insurance, and Liquidity. The Journal of Political Economy, 91(3), pp. 401-419.

FOBAPROA (October 29, 1998). El Fondo Bancario de Protección al Ahorro y la tradición de protección a los ahorradores bancarios. Available online at $<$ http://www.fobaproa. gob.mx/fobaproa/foba/sitactual/e11.htm>

FOBAPROA (October 29, 1998). El proceso de quiebra del sistema bancario. Available online at <http://www.fobaproa.gob.mx/fobaproa/foba/sitactual/e1.htm>

FOBAPROA (November 30, 1998). "1. Primera iniciativa". Available online at $<$ http://ww w.fobaproa.gob.mx/fobaproa/foba/inicrefo/ primera.htm>

FOBAPROA (November 30, 1998). "2. Seguna iniciativa". Available online at $<$ http://ww w.fobaproa.gob.mx/ fobaproa/foba/inicrefo/ segunda.htm>

Gavito, J., A. Silva, and G. Zamarripa (1998). Recovery after Crisis: Lessons for Mexico's Banks and Private Sector. In Roett, R. (Ed.). Mexico's Private Sector: Recent History, Future Challenges. Boulder: Lynne Rienner Publishers.

González-Anaya, J. (2002). Why Have Banks Stopped Lending in Mexico since the Peso Crisis in 1995. Center for Research on Economic Development and Policy Reform. Working Paper 118 (Stanford University).

Greene, W. (2000). Econometric Analysis. 4th edition, Prentice Hall, N.J.

Heath, J. (1999). Mexico Today: Bouncing Back from the Peso Crash. Business Economics, 34(3), pp. 15-21.

Hernández, F. and O. López (2001). La crisis bancaria mexicana: un modelo de duración y riesgo proporcional. El Trimestre Económico, 272, pp. 551-602.

Hernández, F. and O. López (2001). La Banca en México, 1995-2000. Economía Mexicana: Nueva Epoca, CIDE.

INEGI (May, 2003). URL: http://www.inegi.gob.mx

Kaminsky, G. and C. Reinhart (1999). The Twin Crises: The Causes of Banking and Balance-of-Payments Problems. American Economic Review, 89(3), pp. 473-500.

Kane, E. (1985). The Gathering Crisis in Federal Deposit Insurance, Cambridge, Mass.: MIT Press.

Kane, E. (1989). The S\&L Insurance Mess: How Did it Happen? Washington, D. C.: The Urban Institute Press.

Krueger, A. and A. Tornell (1999). The Role of Bank Restructuring in Recovering from Crises: Mexico 1995-1998. NBER, Working Paper 7042.

La Porta, R., F. Lopez-de-Silanes, and G. Zamarripa (2003). Related Lending. Quarterly Journal of Economics, 118, pp. 231-268.

Mackey, M. (1999). Report of Michael W. Mackey on the Comprehensive Evaluation of the Operations and Functions of the Fund for the Protection of Bank Savings "FOBAPROA" and Quality of Supervision of the FOBAPROA Program 1995-1998. Submitted to the Congress of Mexico, July.

Naranjo-González, M. (2000). Evolución del seguro de dépositos en México. CNBV, Documento de Investigación 2000-02.

Stiglitz, J. and A. Weiss (1981). Credit Rationing in Markets with Imperfect Information. American Economic Review, 71(3), pp. 393-410. 
O'Driscoll, G. (1988). Bank Failures: The Deposit Insurance Connection. Contemporary Policy, 6, pp. 1-12.

Wheelock, D. and S. Kumbhakar (1995). Which Banks Choose Deposit Insurance? Evidence of Adverse Selection and Moral Hazard in a Voluntary Insurance System. Journal of Money, Credit and Banking. 27(1), pp. 186-201.

Wheelock, D. and P. Wilson (1995). Explaining Bank Failures: Deposit Insurance, Regulation, and Efficiency. The Review of Economics and Statistics, 77(4), pp. 689-700. 